\title{
JEKK
}

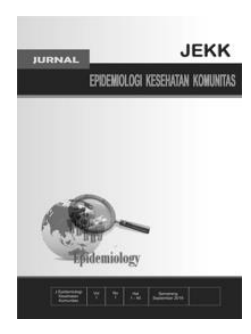

\section{Hubungan Tingkat Pengetahuan dan Tingkat Kepatuhan Minum Obat dengan Tingkat Kekambuhan Lupus Eritematosus Sistemik}

\author{
Dinda Sinta Rahayu*, Ari Udijono*, Lintang Dian Saraswati* \\ * Bagian Epidemiologi dan Penyakit Tropik, Fakultas Kesehatan Masyarakat \\ Universitas Diponegoro, Semarang
}

\begin{abstract}
Background: Systemic Lupus Erythematosus (SLE) is an autoimmune disease with varied manifestations and characterized by recurring flares. Lack of disease knowledge and non-compliance with drug therapy are an important cause of not achieving treatment targets and worsening lupus symptoms.

Methods: This research is a descriptive study with a cross-sectional approach. The research method is quantitative. The sample in this study were 136 patients who came to examine themselves at Central-General Hospital in Semarang City. The sampling technique used in this study was total sampling. This study used a questionnaire to determine the variables studied.

Result: The results of this study indicate a significant correlation between the level of knowledge $(r=-0,332 ; p<0,05)$ and level of drug adherence $(r=-0,644 ; p<0,05)$ to the level of systemic lupus erythematosus flares.

Conclusion : Based on the results, there is a correlation between knowledge and drug adherence to the level of systemic lupus erythematosus flares. The recommendation given is an integrated approach between patients and health care providers to improve patients understanding of systemic lupus erythematosus flares. Beside of that, specific attention should be paid to integrate the service provision system into the collaborative approach of the patients and his/her family in order to promote the level of drug adherence.
\end{abstract}

Keywords: Systemic lupus erythematosus; flares; knowledge; adherence.

*Penulis korepondensi, dindasinta13@gmail.com 


\section{Pendahuluan}

Lupus Eritematosus Sistemik (LES) adalah penyakit autoimun yang multisistem, kronis, memiliki perjalanan penyakit yang bervariasi dan penyebabnya belum diketahui secara pasti. ${ }^{1}$ Munculnya LES diawali dari adanya proses interaksi antara gen yang dicurigai dan faktor lingkungan yang menimbulkan respon abnormal pada tubuh. ${ }^{2}$ Respon abnormal tersebut antara lain adalah proses autoantibodi yang menyebabkan tidak terkendalinya kompleks imun yang dapat menimbulkan gejala konstitusional atau gejala pada organ spesifik. ${ }^{3,4}$

LES merupakan penyakit yang jarang terjadi tetapi digolongkan dalam penyakit yang serius. ${ }^{5}$ The Lupus Foundation of America memperkirakan terjadi kenaikan kasus baru lupus sekitar 16 ribus kasus setiap tahunnya. ${ }^{6}$ Sementara itu, di Amerika Bagian Utara, Amerika Bagian Selatan, Eropa, dan Asia, diperkirakan estimasi incidence rate LES sebesar 1 hingga 25 kasus per 100.000 penduduk. $^{7,8}$ Sementara di Indonesia, prevalensi kasus LES sebesar $0,5 \%$ terhadap populasi masyarakat. ${ }^{6}$

LES adalah penyakit yang tidak dapat disembuhkan, tetapi bisa dikontrol atau di manajemen melalui pengobatan. ${ }^{9}$ Tujuan dari pengobatan LES adalah pasien dapat terhindar dari fase kekambuhan. Fase kekambuhan adalah fase dimana munculnya kembali aktivitas penyakit dari LES yang diderita akibat adanya interaksi antara faktor genetik, hormonal, dan lingkungan berkelanjutan yang menimbulkan respon autoantibodi. Oleh karena itu, meskipun penderita LES dapat memasuki masa remisi, namun risiko untuk mengalami kekambuhan masih tetap tinggi dikarenakan proses autoimun yang terus berlanjut dalam tubuh. ${ }^{10,11}$

Berdasarkan penelitian yang dilakukan di Yunani pada tahun 2017, diketahui bahwa 20$25 \%$ penderita LES akan mengalami kekambuhan dalam 1-2 tahun, dan 40-60\% dalam waktu 5-10 tahun. ${ }^{12,13}$ Adapun kekambuhan yang terjadi pada penderita umumnya adalah kekambuhan ringan dan sedang yaitu sebanyak $70-80 \%$ dan $20-30 \%$ lainnya merupakan kekambuhan berat. $^{12}$ Meskipun demikian, jika seseorang sering mengalami kekambuhan baik ringan atau sedang, maka orang tersebut dapat mengalami derajat kerusakan pada tubuh yang lebih parah dibandingkan orang yang jarang mengalami kekambuhan.

Akibat tingginya risiko peningkatan morbiditas dan mortalitas akibat kekambuhan LES, The Lupus Foundation of America mencanangkan program pengobatan lupus terpadu dengan menggabungkan beberapa jenis kelompok obat, baik imunosupresan, antimalaria, prednisone, dan kortikosteroid. ${ }^{1,9} \mathrm{Di}$ Indonesia, Kementerian Kesehatan mencanangkan upaya pengendalian lupus terpadu dengan menerbitkan tatalaksana umum pengobatan pasien LES dan penggiatan pelaksanaan SALURI (Periksa Lupus Sendiri). Dari upaya yang telah dilakukan, diketahui bahwa inti dari pencegahan kekambuhan LES adalah dilakukannya pengobatan dan juga pengontrolan lupus rutin. Meskipun demikian, tantangan dari pengobatan lupus yang diharuskan untuk terus menerus mengakibatkan penderitanya tidak patuh untuk melakukan pengobatan. ${ }^{6}$

Berdasarkan studi di Amerika, disebutkan bahwa tingkat ketidakpatuhan minum obat pada penderita LES dewasa adalah 43-75\%, dan $33 \%$ penderita menghentikan minum obat setelah 5 tahun menjalani masa pengobatan. ${ }^{1}$ Selain itu, berdasarkan studi lainnya, disebutkan pula bahwa penderita yang tidak rutin minum obat memiliki risiko lebih tinggi berobat ke Instalasi Gawat Darurat (IGD) hingga 1,45 kali dibandingkan dengan penderita yang rutin minum obat $(p<0,05) .{ }^{14}$ Tingginya angka ketidakpatuhan pengobatan pada penderita LES sering dikaitkan dengan pengetahuan penderita mengenai LES yang diderita. Penelitian yang dilakukan di Surabaya tahun 2016, diketahui bahwa dari 100\% penderita LES dengan tingkat pengetahuan yang tinggi, $77,8 \%$ diantaranya melakukan tindakan pencegahan gejala lupus secara optimal dan $22,8 \%$ sisanya tidak melaksanakan tindakan pencegahan secara optimal. ${ }^{15} \mathrm{Hal}$ ini berbeda dengan penelitian yang dilakukan di Riyadh, Saudi Arabia yang menunjukkan bahwa tidak terdapat hubungan signifikan antara pengetahuan tentang lupus dengan munculnya gejala lupus $(p>0,05){ }^{16}$ 
Di Kota Semarang, berdasarkan hasil studi pendahuluan di RSUP Dr. Kariadi, diketahui bahwa terjadi peningkatan prevalensi kejadian LES selama 3 tahun terakhir sejak tahun 2016 hingga tahun 2018. Prevalensi LES pada tahun 2016 adalah 5,1 kasus per 100.000 penduduk, pada tahun 2017 sebesar 6,4 per 100.000 penduduk, dan pada tahun 2018 sebesar 7,3 kasus per 100.000 penduduk. Dalam kaitannya dengan kekambuhan, upaya sosialisasi dan pencegahan kekambuhan terus digiatkan di antara penderita LES. Upaya yang dilakukan bertujuan untuk meningkatkan kualitas hidup bagi penderita LES melalui pencegahan kekambuhan dan juga komplikasi dari LES yang diderita. Meskipun demikian, hingga saat ini kejadian kekambuhan belum bisa dicegah dan masih adanya kasus rawat inap akibat kekambuhan yang parah.

Sampai saat ini, penelitian terkait kekambuhan pada penderita LES belum banyak dilakukan. Di sisi lain, kekambuhan pada penderita LES harus mendapatkan perhatian lebih, sebab kekambuhan dapat meningkatkan risiko kesakitan dan kematian yang lebih tinggi dan menurunnya kualitas hidup dari penderita. Berdasarkan hal tersebut, maka peneliti tertarik ingin meneliti hubungan pengetahuan dan kepatuhan minum obat dengan tingkat kekambuhan lupus eritematosus sistemik.

\section{Metode}

Penelitian ini merupakan penelitian deskriptif dengan pendekatan cross-sectional. Populasi penelitian ini adalah seluruh penderita Lupus Eritematosus Sistemik yang menjalankan pengobatan di Rumah Sakit Umum Pemerintah di Kota Semarang. Besar sampel dalam penelitian ini dihitung dengan menggunakan rumus uji hipotesis beda 2 proporsi dan didapatkan sampel minimal sebanyak 84 responden. Dalam penelitian ini jumlah sampel diambil dari seluruh populasi studi dengan penerapan kriteria eksklusi yaitu pasien menderita penyakit autoimun lain seperti rheumatoid arthritis, psoriasis, inflammatory bowel disease, multiple sclerosis, pasien mengalami kehamilan, serta pasien yang dalam masa pengambilan data sudah meninggal dunia sehingga didapat jumlah sampel penelitian berjumlah 136 responden. Data primer diambil dengan menggunakan angket dalam bentuk google form sedangkan data sekunder diperoleh dari rekam medis rumah sakit, database Komunitas Lupus Panggon Kupu Semarang dan studi literatur.

Variabel independen dalam penelitian ini adalah tingkat kekambuhan LES yang diukur dengan melihat beberapa aspek, yaitu ada tidaknya penambahan obat dan hasil konsultasi terakhir dengan dokter; ada tidaknya trombositpenia dan proteinuria berdasarkan hasil pemeriksaan laboratorium; dan gejala kekambuhan LES yang dirasakan pasien, yang setiap aspek pertanyaannya disesuaikan dengan Systemic Lupus Erythematosus Disease IndexSelena Modification (SELENA-SLEDAI) dan indikator gejala LES berdasakan program SALURI (Periksa Lupus Sendiri) yang dicanangkan Pemerintah melalui Kementrian Kesehatan. Variabel dependen terdiri dari tingkat pengetahuan dan tingkat kepatuhan minum obat. Tingkat pengetahuan diukur dengan menggunakan angket untuk mengukur pengetahuan yang berisi 10 pertanyaan terkait dengan LES. Sementara itu, tingkat kepatuhan minum obat diukur dengan melihat kesesuaian antara praktik minum obat dan anjuran dokter serta menggunakan Medication Morisky Adherence Scale (MMAS-8) yang terdiri dari 8 pertanyaan untuk mengukur kepatuhan.

Analisis data yang dilakukan meliputi analisis univariat dan analisis bivariat. Analisis univariate yaitu untuk melihat distribusi frekuensi tiap variabel dan analisis bivariat untuk menganalisis hubungan variabel bebas yaitu tingkat pengetahuan penderita mengenai LES dan tingkat kepatuhan minum obat dengan variabel terikat tinglat kekambuhan LES. Uji statistik yang digunakan yaitu menggunakan korelasi Spearman. 


\section{Hasil}

\section{Karakteristik Responden}

Tabel 1 Distribusi Frekuensi Karakteristik Responden

\begin{tabular}{lrr}
\hline Karakteristik Responden & N & \% \\
\hline Usia & & \\
\hline 15-50 tahun & 126 & 92,6 \\
$>50$ tahun & 10 & 7,4 \\
\hline Jenis Kelamin & & \\
\hline Perempuan & 130 & 95,6 \\
Laki-Laki & 6 & 4,4 \\
\hline Jenis Obat & & \\
\hline Imunosupresan & 92 & 67,6 \\
Kortikosteroid & 30 & 22,0 \\
Gabungan (Imunosupresan & 13 & 9,5 \\
dan Kortikostreoid) & & \\
Antimalaria & 1 & 0,7 \\
\hline
\end{tabular}

a. Usia

Berdasarkan Tabel 1, diketahui bahwa sebagian besar penderita LES berusia $15-50$ tahun $(92,6 \%)$.

b. Jenis Kelamin

Berdasarkan Tabel 1, diketahui bahwa sebagian besar penderita LES berjenis kelamin perempuan $(95,6 \%)$.

c. Jenis Obat

Berdasarkan Tabel 1, diketahui bahwa sebagian besar penderita LES mengonsumsi obat jenis imunosupresan $(67,6 \%)$

\section{Gambaran Tingkat Pengetahuan}

Tabel 2. Distribusi Frekuensi Tingkat Pengetahuan mengenai LES dan Kekambuhan LES

\begin{tabular}{llr}
\hline \multicolumn{1}{c}{ Indikator } & N & \multicolumn{1}{c}{$\%$} \\
\hline Definisi & 136 & 100,0 \\
Gejala Spesifik & 136 & 100,0 \\
Faktor Risiko & 136 & 100,0 \\
Bentuk dan Gejala & 136 & 100,0 \\
Klinis & 129 & 94,8 \\
Tujuan Pengobatan & 114 & 83,8 \\
Jenis-Jenis & 123 & 90,4 \\
Pengobatan & & \\
Kekambuhan LES &
\end{tabular}

\begin{tabular}{lcr}
\hline $\begin{array}{l}\text { Kondisi yang } \\
\text { Menyebabkan }\end{array}$ & 133 & 97,7 \\
$\begin{array}{l}\text { Kambuh } \\
\text { Bentuk Gejala }\end{array}$ & 132 & \\
$\begin{array}{l}\text { Kekambuhan } \\
\text { Faktor Risiko }\end{array}$ & 136 & 100,0 \\
Kekambuhan & & \\
\hline
\end{tabular}

Berdasarkan Tabel 2, diketahui seluruh responden telah mengetahui definisi, gejala spesifik, faktor risiko, bentuk dan gejala klinis dari LES. (100\%). Sementara itu, pengetahuan mengenai tujuan pengobatan, jenis-jenis pengobatan, definisi kekambuhan LES, dan bentuk gejala kekambuhan belum mencapai angka 100\%. Hal ini menandakan bahwa masih ada responden yang tidak mengetahui indikator dari penilaian pengetahuan tersebut.

\section{Gambaran Tingkat Kepatuhan Minum Obat}

Tabel 3 Distribusi Frekuensi Kesesuaian Praktik Minum Obat

\begin{tabular}{llr}
\hline \multicolumn{1}{c}{ Indikator } & N & \% \\
\hline Sesuai & 112 & 82,4 \\
\hline Tidak Sesuai & 24 & 17,6
\end{tabular}

Berdasarkan Tabel 3, diperoleh bahwa dari 136 Pasien LES sebagian besar pasien $(82,4 \%)$ minum obat sesuai dengan aturan yang disarankan oleh dokter.

Tabel 4 Distribusi Frekuensi Jawaban Responden Berdasarkan Morisky Medication Adherence Scale (MMAS)

\begin{tabular}{lrccc}
\hline \multicolumn{1}{c}{$\begin{array}{c}\text { Indikator } \\
\text { Pertanyaan }\end{array}$} & \multicolumn{2}{c}{ Ya } & \multicolumn{2}{c}{ Tidak } \\
\cline { 2 - 5 } & $\mathbf{f}$ & $\mathbf{f}$ & $\%$ \\
\hline $\begin{array}{l}\text { Tidak minum } \\
\text { obat sesuai }\end{array}$ & & & \\
dengan aturan & 43 & 31,6 & 93 & 68,4 \\
dalam se- & & & & \\
minggu & & & & \\
terakhir & & & & \\
$\begin{array}{l}\text { Sengaja tidak } \\
\text { minum obat } \\
\text { karena kondisi }\end{array}$ & 36 & 26,5 & 100 & 73,5 \\
\hline
\end{tabular}


memburuk

\begin{tabular}{|c|c|c|c|c|}
\hline $\begin{array}{l}\text { Sengaja tidak } \\
\text { minum obat } \\
\text { karena merasa } \\
\text { sehat }\end{array}$ & 59 & 43,4 & 77 & 56,6 , \\
\hline $\begin{array}{l}\text { Tidak } \\
\text { membawa } \\
\text { obat ketika } \\
\text { bepergian }\end{array}$ & 60 & 44,1 & 76 & 55,9 \\
\hline $\begin{array}{lr}\text { Tidak } & \text { minum } \\
\text { obat } & \text { sesuai } \\
\text { dengan } & \text { aturan } \\
\text { di } & \text { hari } \\
\text { kemarin } & \\
\end{array}$ & 72 & 52,9 & 64 & 47,1 \\
\hline $\begin{array}{l}\text { Berhenti } \\
\text { minum obat } \\
\text { tanpa } \\
\text { sepengetahuan } \\
\text { dokter }\end{array}$ & 61 & 44,9 & 75 & 55,1 \\
\hline $\begin{array}{l}\text { Merasa } \\
\text { terganggu } \\
\text { dalam } \\
\text { menjalani } \\
\text { pengobatan } \\
\end{array}$ & 60 & 44,1 & 76 & 55,9 \\
\hline $\begin{array}{l}\text { Merasa } \\
\text { kesulitan } \\
\text { dalam minum } \\
\text { obat }\end{array}$ & 42 & 30,9 & 94 & 69,1 \\
\hline $\begin{array}{l}\text { Berdasarka } \\
\text { bahwa sebagia } \\
\text { pasien meminur } \\
\text { aturan di wakt } \\
\text { angket penelitia }\end{array}$ & \multicolumn{4}{|c|}{$\begin{array}{l}\text { Tabel } 4 \text { diperoleh hasil } \\
n \text { besar pasien }(52,9 \%) \\
n \text { obat tidak sesuai dengan } \\
\text { sehari sebelum mengisi } \\
\text { n. }\end{array}$} \\
\hline
\end{tabular}

\section{Hasil Analisis Bivariat}

Tabel 5 Hasil Analisis Bivariat

\begin{tabular}{llll}
\hline \multicolumn{1}{c}{ Variabel } & \multicolumn{1}{c}{$\begin{array}{c}\text { Uji } \\
\text { Statistik }\end{array}$} & Nilai $\boldsymbol{p}$ & $\begin{array}{c}\text { Nilai } \\
\text { r }\end{array}$ \\
\hline Tingkat & Uji & $0,000^{*}$ & - \\
Pengetahuan & Korelasi & & 0,332 \\
tentang & Spearman & & \\
Lupus & & & \\
Eritematosus & & & \\
Sistemik & & & \\
\hline Tingkat & Uji & $0,000^{*}$ & - \\
Kepatuhan & Korelasi & & 0,644 \\
Minum Obat & Spearman & & \\
\hline Ket: (signifikn) & &
\end{tabular}

Ket: * (signifikan) a. Tingkat Pengetahuan

Berdasarkan Tabel 5 diketahui bahwa terdapat hubungan signifikan antara tingkat pengetahuan dengan tingkat kekambuhan LES ( $p<0,05 ; \mathrm{r}=-0,332)$.

b. Tingkat Kepatuhan Minum Obat Berdasarkan Tabel 5 diketahui bahwa terdapat hubungan antara tingkat kepatuhan minum obat dengan tingkat kekambuhan LES ( $p<0,05 ; r=-0,644)$.

\section{Pembahasan}

Dalam teori Precede Procede Model dari Larwrence Green dan Kreter, pengetahuan termasuk dalam domain faktor predisposisi perilaku kesehatan yang dapat secara langsung mempengaruhi gaya hidup/tindakan yang diambil seseorang untuk mempertahankan status kesehatannya. ${ }^{17}$ Pengetahuan manusia diperoleh melalui persepsinya terhadap stimulus dengan menggunakan alat indra, dimana hasil dari persepsi informasi akan disimpan dalam sistem memori untuk diolah dan diberikan makna. Informasi yang disimpan tersebut nantinya digunakan pada saat diperlukan. ${ }^{18}$ Informasi dapat mempengaruhi pengetahuan penderita mengenai sistemik lupus eritematosus, pengobatannya, dan termasuk bagaimana caranya terhindar dari kekambuhan lupus yang mungkin dapat terjadi.

Penelitian terkait hubungan tingkat pengetahuan dengan tingkat kekambuhan lupus eritematosus sistemik di Tiongkok menunjukkan bahwa adanya hubungan yang signifikan. Pada penelitian tersebut, disebutkan bahwa kurangnya informasi mengenai penyakit LES yang diderita merupakan salah satu faktor yang berhubungan dengan terjadinya flares pada penderita LES. ${ }^{19}$

Pada penelitian ini, pengetahuan memiliki hubungan yang bermakna dengan tingkat kekambuhan LES. Nilai dari koefisien korelasi menunjukkan adanya hubungan yang negatif yang artinya semakin tinggi tingkat pengetahuan semakin rendah tingkat kekambuhan yang dialami pasien. Hasil sebar kuesioner 
menunjukkan bahwa sebagian besar pasien sudah mengetahui apa itu penyakit lupus eritematosus sistemik dan faktor-faktor yang menyebabkan terjadinya kekambuhan dari lupus yang diderita. Sebagian besar pasien mengetahui apa sebenarnya definisi dari kekambuhan lupus yaitu berupa kondisi munculnya kembali gejala lupus pada penderita. Selain itu, lebih dari setengah responden juga telah mengetahui apa saja bentuk gejala dari kekambuhan lupus eritematosus sistemik.

Tingkat pengetahuan mengenai penyakit yang diderita, termasuk didalamnya kesadaran akan risiko tinggi dari penyakit untuk mengalami kekambuhan merupakan hal mendasar yang berpengaruh terhadap cara berpikir dan bertindak dari penderita. Pengetahuan yang baik mengenai penyakit akan membentuk sifat waspada pada penderita untuk selalu paham dan siap siaga jika dalam masa penyakitnya muncul gejala kekambuhan yang mengarah pada terbentuknya respon untuk segera melakukan pengobatan. Pengetahuan yang rendah menyebabkan sulitnya penderita untuk mengenali tanda dan gejala bahaya yang mungkin timbul dari sakit yang diderita yang dapat mengarah pada terlambatnya pengobatan dan meningkatnya risiko kesakitan dan kematian pada penderita.

Kepatuhan pasien didefinisikan sebagai sejauh mana perilaku pasien sesuai dengan ketentuan profesional kesehatan. ${ }^{20}$ Kepatuhan merupakan aspek penting dalam proses pencegahan kekambuhan maupun penyembuhan penyakit pasien. Pasien atau penderita akan melaksanakan cara pengobatan yang berlaku sesuai dengan yang disarankan oleh dokter atau oleh yang lain sehingga proses penyembuhan berjalan sebagaimana mestinya. ${ }^{21}$ Berbanding terbalik dengan kepatuhan, ketidakpatuhan pengobatan akan meningkatkan risiko berkembangnya masalah kesehatan yang dapat memperpanjang atau memperburuk kesakitan yang sedang diderita. Tingkat ketidakpatuhan dalam melakukan pengobatan terbukti cukup tinggi dalam seluruh populasi medis yang kronis, dimana pasien yang mengalami pengobatan dan perawatan dalam jangka waktu yang lama, umumnya akan mengalami penurunan tingkat kepatuhan dibandingkan pada populasi medis dengan penyakit non kronis atau penyakit yang memiliki jangka waktu pendek. ${ }^{20}$ Kepatuhan pasien lupus atau odapus dalam melakukan pengobatan merupakan perilaku yang sangat menunjang status remisi dan kekambuhan mereka.

Penelitian terkait hubungan tingkat kepatuhan dengan tingkat kekambuhan lupus eritematosus sistemik di University of California, San Fransisco menyebutkan bahwa penderita LES pernah lupa mengonsumsi obat setidaknya satu kali. Pada penelitian tersebut, disebutkan pula bahwa penderita yang tidak rutin minum obat memiliki risiko lebih tinggi berobat ke Instalasi Gawat Darurat hingga 1,45 kali lipat dibandingkan penderita yang rutin minum obat. ${ }^{14}$ Sementara itu, pada penelitian yang dilakukan di klinik reumatologi yang bergabung dengan University of Cincinnati dan Ohio State University, dihasilkan bahwa tingkat ketidakpatuhan minum obat sebesar 43$75 \%$ dan sebanyak $33 \%$ penderita menghentikan obatnya sendiri setelah 5 tahun. Ketidakpatuhan ini dapat terjadi karena kurangnya pengetahuan penderita mengenai LES, polifarmasi (banyaknya obat yang diminum) dan depresi. ${ }^{22}$ Pada penelitian ini, kepatuhan memiliki hubungan yang bermakna dengan tingkat kekambuhan LES. Nilai dari koefisien korelasi menunjukkan adanya hubungan yang negatif yang artinya semakin tinggi tingkat kepatuhan pengobatan semakin rendah tingkat kekambuhan yang dialami pasien. Hasil sebar kuesioner menunjukkan bahwa setengah dari responden yang dteliti tidak meminum obat sesuai dengan aturan pada waktu sehari sebelum pengambilan data, selain itu ada beberapa responden yang juga tidak minum obat sesuai dengan aturan dalam satu minggu terakhir dan berhenti minum obat tanpa sepengetahuan dokter 


\section{Kesimpulan}

Tingkat pengetahuan tentang LES ( $p=0,000$; $\mathrm{r}=-0,332)$ dan tingkat kepatuhan minum obat ( $p=0,000 ; \mathrm{r}=-0,644)$ memiliki hubungan yang signifikan dengan tingkat kekambuhan lupus eritematosus sistemik.

\section{Ucapan Terima Kasih}

Terima kasih kepada Bagian Reumatologi RSUP Dr. Kariadi dan Komunitas Lupus Panggon Kupu Semarang yang telah membantu dalam pengumpulan data.

\section{Daftar Pustaka}

1. Hikmah Z, Prihaningtyas RA. 2018. Bersahabat dengan lupus. Jakarta: PT Elex Media Komputindo..

2. Kamphuis S, Silverman ED. 2010. Prevalence and burden of pediatric-onset systemic lupus erythematosus. Nat Rev Rheumatol [Internet]. 6(9):538-46. Available

from:http://dx.doi.org/10.1038/nrrheum.20 10.121

3. Abbas AK, Aster JC, Kumay V. 2014. Buku ajar patologi robbins. 9th ed. Nasar IM, Cornain S, editors. Singapura: Elsevier saunders;.

4. Silva CA, Avcin T, Brunner HI. 2012. Taxonomy for systemic lupus erythematosus with onset before adulthood. Arthritis Care Res (Hoboken). 64(12):1787-93.

5. Farkhati MY, Hapsara S, Satria CD. 2012. Antibodi anti DS-DNA sebagai faktor prognosis mortalitas pada lupus eritematosus sistemik. Sari Pediatr. 14(2):90-6.

\section{Kementrian Kesehatan Republik Indonesia. 2017. Situasi lupus di Indonesia. Jakarta.}

7. Pons-Estel GJ, Alarcon GS, Scofield L,
Reinlib L, Cooper GS. 2010. Understanding the epidemiology and progression of systemic lupus erythematosus. Semin Arthritis Rheum [Internet]. 39(4):257. Available from: https://www.ncbi.nlm.nih.gov/pmc/articles /PMC2813992/pdf/nihms104220.pdf

8. Danchenko N, Satia JA, Anthony M. 2006. Epidemiology of systemic lupus erythematosus: a comparison of worldwide disease burden. Sage.15(5):308-18.

9. Wallace DJ. 2007. The lupus book. 1st ed. Wiratama C, editor. Bandung: B-First;.

10. Lipsky P. 2001. Systemic lupus erythematosus: An autoimmune disease of B cell hyperactivity. Nature Immunology [Internet]. Sep;764-6. Available from: http://immunol.nature.com

11. Zharkova O, Celhar T, Cravens PD, Satterthwaite AB, Fairhust AM, Davis LS. 2017. Pathways leading to an immunological disease: systemic lupus erythematosus. $\mathrm{Br}$ Soc Rheumatol [Internet]. 56(1):55-66. Available from: www.rheumatology.oxfordjournals.org

12. Adamichou C, Bertsias G. 2017. Flares in systemic lupus erythematosus: diagnosis, risk factors and preventive strategies. Mediterr J Rheumatol [Internet]. 28(1):412. Available from: https://doi.org/10.31138/mjr.28.1.4

13. Conti F, Ceccarelli F, Perricone C, Miranda F, Truglia S, Massaro L, et al. 2012. Flare, persistently active disease, and serogically active clinically quiescent disease in systemic lupus eryhthematosus: a 2-year follow-up study. PLoS One [Internet]. 7(9):1-6. Available from: https://doi.org/10.1371/journal.pone.00459 34

14. Julian LJ, Yelin E, Yazdany J, Panopalis P, Trupin L, Criswell LA, et al. 2009. Depression, medication adherence, and service utilization in systemic lupus 
erythematosus. Arthritis Rheum.; 1(2):240-6.

15. Sari NPWP. 2015. Faktor pencetus gejala dan perilaku pencegahan sistemic lupus erythematosus. J Ners. 11(2):213-9.

16. Bin Haikel KA, Al Tulaihi B. 2018. Awareness of systemic lupus erythematosus among primary health care patients in Riyadh, Saudi Arabia. Maced J Med Sci [Internet]. 6(12):2386-92. Available from: https://www.idpress.eu/mjms/index

17. Notoatmodjo S. 2012. Promosi kesehatan dan perilaku kesehatan. Jakarta: Rineka Cipta;

18. Ukwaja KN, Alobu I, Nweke CO, Onyenwe EC. 2013. Healthcare-seeking behavior, treatment delays and its determinants among pulmonary tuberculosis patients in rural Nigeria: a cross-sectional study. BMC Health Serv Res. 13(25):1-9.

19. Zhang L, Luan W, Geng S, Ye S, Wang X, Qian L, et al. 2019. Lack of patient education is risk factor of disease flare in patients with systemic lupus erythematosus in China. BMC Health Serv Res. 19(1):18.

20. Niven N. 2000. Psikologi kesehatan edisi kedua. Pengantar untuk perawat dan profesional kesehatan lain. 2nd ed. Jakarta: EGC Penerbit Buku Kedokteran;.

21. Smet B. 1994. Psikologi Kesehatan. Jakarta: PT. Gramedia.

22. Koneru S, Kocharla L, Higgins GC, Ware A, Passo MH, Farhey YD, et al. 2008. Adherence to medications in systemic lupus erythematosus. J Clin Rheumatol.;14(4):195-201. 